\title{
Basic FGF in Astroglial, Microglial, and Neuronal Cultures: Characterization of Binding Sites and Modulation of Release by Lymphokines and Trophic Factors
}

\author{
Dalia M. Araujo and Carl W. Cotman \\ Department of Psychobiology, University of California, Irvine, California 92717
}

The present study characterizes whether basic fibroblast growth factor (bFGF) is present and released from astroglia, microglia, and hippocampal neurons in vitro. For cell content, bFGF-like immunoreactivity (IR) of cell extracts was measured, whereas release was determined by assessing the levels of bFGF-like IR in media. In addition, the effects of Iymphokines and trophic factors that are known to be released from these cells on bFGF release were examined. For all three cell types, bFGF-like IR in extracts of cell lysates was detectable. In addition, media content was highest in astroglial cultures and lowest in neuronal cultures. Although bFGF-like IR of neuronal and microglial media appeared to increase with time in culture, this was likely due to significant astroglial proliferation. Thus, notable levels of bFGF are released by astroglia in vitro. In astroglia, bFGF release was enhanced by interleukin-1 (IL-1), IL-6, and epidermal growth factor (EGF), but not by other lymphokines or NGF. In contrast, bFGF in microglial media was reduced by IL-3, EGF, and NGF, but slightly augmented by $\boldsymbol{\gamma}$-interferon (IFN); other Iymphokines were ineffective. In addition, no effects were seen in the neuronal cultures. It is likely that the bFGF found in glial media interacts with bFGF receptors since in both glial and neuronal cell types, a single class of low-capacity $\left(B_{\max }\right)$, high-affinity $\left(K_{d}\right)$ bFGF binding sites was evident. The possibility that endogenous bFGF acts as an autocrine factor for astroglia was further supported by experiments that tested the mitogenic effects of exogenous bFGF on glial cells. bFGF significantly enhanced ${ }^{3} \mathrm{H}$-thymidine uptake into astroglial, but not microglial, cells in vitro. Thus, the present study demonstrates that a complex regulation of glial bFGF release by astroglia and microglia occurs in vitro. Moreover, the results are consistent with an autocrine role for bFGF in astroglial cultures.

Basic fibroblast growth factor (bFGF) is a member of a large family of structurally related polypeptide growth factors that includes acidic FGF (aFGF) and several oncogene products (for reviews, see Baird and Walicke, 1989; Walicke, 1989). bFGF affects the function of a wide variety of cell types (see reviews

\footnotetext{
Received July 22, 1991; revised Nov. 7, 1991; accepted Nov. 26, 1991.

This work was supported by NIA LEAD Award AG07918-02. D.M.A. was supported by a Centennial Fellowship of the Medical Research Council of Canada. We are grateful to Dr. Paul Lapchak for his careful proofreading of the manuscript. Correspondence should be addressed to Dalia M. Araujo, Andrus Gerontology Center, University of Southern California, University Park MC-0191, Los Angeles, CA 90089-0191.

Copyright (C) 1992 Society for Neuroscience $0270-6474 / 92 / 121668-11 \$ 05.00 / 0$
}

by Baird et al., 1986; Gospodarowicz et al., 1986, 1987; Walicke, 1989; Araujo et al., 1990). For example, bFGF has been demonstrated to enhance the survival and neurite outgrowth of both peripheral and central neurons in culture (Morrison et al., 1986; Walicke et al., 1986; Unsicker et al., 1987; Walicke, 1988a; Walicke and Baird, 1988; Ferrari et al., 1989) and to stimulate the activity of basal forebrain neurons (Knusel et al., 1990). Moreover, it appears that unlike NGF, which is mainly a trophic factor for cholinergic neurons of the basal forebrain (for reviews, see Hefti et al., 1989; Lapchak and Hefti, 1991), bFGF acts as a neurotrophic factor for a broad range of CNS neuronal populations (Walicke, 1988a; Matsuda et al., 1990; Murphy et al., 1990). In addition, there is considerable evidence to suggest that bFGF may be a mitogen for astroglia and oligodendroglia in vitro (Morrison and de Vellis, 1981; Pruss et al., 1982; Pettmann et al., 1985; Saneto and de Vellis, 1985).

A variety of tissues are now known to be capable of synthesizing both bFGF and aFGF (Baird et al., 1986; Gospodarowicz et al., 1986; Thomas, 1987), although the cell types that produce bFGF in the CNS have not been conclusively identified. However, evidence from the literature suggests that in the CNS, bFGF may be localized to a broad range of cell types. For instance, immunohistochemical studies have demonstrated the presence of FGF within neurons (Pettmann et al., 1986) and astroglia (Ferrara et al., 1988; Hatten et al., 1988). Moreover, it has been proposed that bFGF derived from glia may promote neuronal survival and neurite extension (Hatten et al., 1988). However, because the FGFs lack a distinct signal sequence (Esch et al., 1985; Abraham et al., 1986; Thomas, 1987), the mechanism underlying bFGF release from glia and other cell types remains unclear. Thus far, direct evidence for bFGF release from CNS cells has not been unequivocally demonstrated. Indirect evidence from studies of endothelial (Schweigerer et al., 1987; Flaumenhaft et al., 1990; Tsuboi et al., 1990) and C6 glioma (Okumura et al., 1989) cells in vitro implies that released bFGF, perhaps bound to heparan sulfate, functions as an autocrine factor for these cells. Consistent with this, a recent study showed that endothelial bFGF is released from bFGF-heparan sulfate complexes and subsequently binds to high-affinity receptors on these same cells (Saksela and Rifkin, 1990).

The above findings imply that since both neurons and glia are responsive to exogenous bFGF, bFGF receptors must be present on both cell types. Evidence for bFGF receptors on neurons has been obtained from studies using autoradiographic localization of ${ }^{125}$ I-bFGF binding sites in vitro (Walicke, 1988b; Walicke et al., 1989) and in vivo (Ferguson et al., 1990). In addition, FGF receptor mRNA has been identified in specific 
neuronal subpopulations in the CNS (Wanaka et al., 1990). Preliminary results have indicated that ${ }^{125} \mathrm{I}-\mathrm{bFGF}$ binding sites also may be present on astroglia (Walicke and Baird, 1988). However, an extensive characterization of bFGF binding sites in glia has not yet been demonstrated.

In view of the meager evidence for bFGF as an autocrine factor for CNS cells, the main objective of the present study was to determine whether bFGF is released from three different CNS cell types in vitro. Thus, the presence of bFGF in media and cell lysates of astroglia, microglia, and hippocampal neurons was established. In addition, possible alterations of bFGF release by other factors that are known to be released from and to affect the function of these different cell types were assessed. The presence of $b F G F$ receptor sites and their responsiveness to exogenous bFGF were determined mainly to establish that there is the potential for endogenous bFGF released from glia and neurons to interact with bFGF receptors on these cells. In this way, endogenous glia- or neuronal-derived bFGF would be of physiological significance to different CNS cell types.

\section{Materials and Methods}

Materials. Timed-pregnant Sprague-Dawley rats and neonatal rat pups [postnatal (P) day 1 to P4] were obtained from Charles River breeding farms (Gilroy, CA). Tissue culture media and supplements were purchased from GIBCO-Bethesda Research Labs (Gaithersburg, MD). ${ }^{3} \mathrm{H}$. thymidine (20-75 Ci/mmol), ${ }^{125} \mathrm{I}-\mathrm{bFGF}$, and radioimmunoassay (RIA) kits for the measurement of bFGF-like immunoreactivity (IR) were bought from Amersham Corp. (Arlington Heights, IL). bFGF, nerve growth factor (NGF), epidermal growth factor (EGF), the interleukins (ILs), and the monoclonal anti-bovine bFGF antibody (type II) used for immunohistochemical detection of $b F G F$ were purchased from Upstate Biotechnology Inc. (Lake Placid, NY). $\gamma$-Interferon (IFN) was from ICN Biomedicals Inc. (Costa Mesa, CA). The polyclonal rabbit antibovine glial fibrillary acidic protein (GFAP) and anti-human neuronspecific enolase (NSE) antibodies were from DAKO Corp. (Carpinteria, CA); the monoclonal antibody for detection of human Mac-1 antigen (anti-Mac-1) was from Boehringer Mannheim (Indianapolis, IN). Elite Vecta-Stain kits containing normal goat serum, biotinylated affinitypurified secondary antibodies, and avidin-biotinylated horseradish peroxidase complexes for the determination of antibody staining were bought from Vector Laboratories (Burlingame, CA). L-Lysine and 3,3'-diaminobenzidine tetrahydrochloride (DAB) were purchased from Sigma Chemical Co. (St. Louis, MO).

Cell culture. Mixed glial cultures were prepared as described by McCarthy and de Vellis (1980). Briefly, the cerebral cortices of neonatal rats (P1-P4) were dissected in Hank's calcium/magnesium-free salt solution, with special emphasis placed on removing the meninges and any noticeable blood clots. The tissues were then transferred in to fresh media and mechanically dissociated. After centrifugation $(200 \times \mathrm{g}, 3 \mathrm{~min})$, tissues were resuspended and triturated with constricted siliconized Pasteur pipettes. The final suspensions were added to $75 \mathrm{~mm}^{2}$ flasks containing 1:1 high-glucose Dulbecco's modified Eagle medium (DMEM) and Ham's F-12, with $20 \%$ fetal calf serum (FCS) added. Media were aspirated and replaced with fresh DMEM/F-12 media containing $10 \%$ FCS after a $24 \mathrm{hr}$ incubation. Thereafter, media (DMEM/F-12/10\% FCS) were aspirated and replenished every 2-3 d.

Microglial cultures, with some contamination from other glial cell types, were obtained at $7-10 \mathrm{~d}$ from confluent mixed glial cultures (Giulian and Baker, 1986; Jordan and Thomas, 1987). Briefly, mixed glial cultures were shaken manually and media containing nonadherent cells were pooled and centrifuged. The resulting pellets were resuspended in media containing $10 \% \mathrm{FCS}$ and triturated as above. The number of viable cclls was detcrmined using the trypan blue exclusion method. Alternatively, the flasks containing adherent cells and fresh media were shaken further (16-24 hr) on an orbital shaker $(200 \mathrm{rpm})$ in a warm room $\left(37^{\circ} \mathrm{C}\right)$, in order to detach microglia and oligodendrocytes. The media were pooled and collected. Cells were then added to plates and were allowed to adhere to the plastic for only $60 \mathrm{~min}$, to minimize attachment of oligodendrocytes to the plate, after which media were again aspirated and replaced with fresh media (Giulian and Baker, 1986).
Subsequently, the adherent cell layer was exposed to $0.25 \%$ trypsin for $10 \mathrm{~min}$; media containing $10 \%$ FCS were then added, and the suspension was collected. Finally, cells were replated in 24 -well plates at a density of $10^{5}$ cells/well and kept for $1 \mathrm{~d}$ prior to use in the indicated experiments.

Astroglial cultures were obtained by adding trypsin $(0.25 \%)$ to flasks containing the adherent cell layer remaining after overnight shaking in a warm room (see above). Subsequently, DMEM/F-12 media containing $10 \%$ FCS were added and the resulting cell suspensions containing mostly detached astroglia were centrifuged. The pellets were resuspended in media, and the cells were then replated (density, $10^{5}$ cells/well), as described above for microglia.

Neuronal cultures of fetal [embryonic day 18 (E18)] hippocampi were prepared as described previously (Mattson et al., 1988; Whitson et al., 1990). Hippocampi were gently triturated, and the resulting cell suspensions were centrifuged and resuspended in media containing $10 \%$ FCS. Cell suspensions $\left(10^{5}\right.$ cells/well $)$ were added to poly-L-lysine-coated 24-well plates and allowed to attach to the surface of the wells for $60 \mathrm{~min}$. Media were then aspirated to remove cellular debris and replaced with fresh media containing $10 \%$ FCS.

For all three cell types studied, prior to determination of experimental measures, media were replaced with reduced-serum media $(2.5-5 \%$ FCS $)$ and the indicated drug(s).

Cell staining. Immunohistochemical localization of markers selective for astroglia, miçroglia, and neurons was used to determine the purity of the different cell cultures. In addition, the presence of bFGF-like IR in these cells was detected using antisera directed against bovine bFGF. The specificity of the bFGF antibody has been extensively characterized (see Gomez-Pinilla et al., 1990); the antibody cross-reacts $100 \%$ with bovine, human, rat, and mouse bFGF and does not cross-react with bovine acidic FGF.

In all cases, cell cultures were fixed in $4 \%$ paraformaldehyde $(10 \mathrm{~min}$ ) and washed $(2 \times 2 \mathrm{~min})$ with phosphate-buffered saline (PBS). Cells were then incubated $\left(22^{\circ} \mathrm{C}, 2 \mathrm{hr}\right)$ in a blocking buffer consisting of Tris$\mathrm{NaCl}(100 \mathrm{~mm}$, pII 7.4), 3\% normal goat serum, and $1.8 \% \mathrm{~L}-$ lysine and washed $(2 \times 2 \mathrm{~min})$ with PBS. Subsequently, cells were incubated (2 $\mathrm{hr}, 22^{\circ} \mathrm{C}$ ) with the Tris- $\mathrm{NaCl}$ buffer containing $1 \%$ Triton $\mathrm{X}-100$ and antibodies directed against GFAP (diluted 1:1000), Mac-1 antigen (diluted $1: 100$ ), or NSE (diluted 1:500), to identify astroglia, microglia, or neurons, respectively. For determination of bFGF-like IR, cells were incubated in the same buffer as above, but with antisera specific to bFGF (diluted 1:500). To assess nonspecific binding for each antibody, adjacent wells were incubated concurrently in the same buffer, but without primary antibody. All cells were then incubated with biotinylated, affinity-purified anti-IgG $\left(1 \mathrm{hr}, 22^{\circ} \mathrm{C}\right)$ and then washed with PBS $(2 \times$ $2 \mathrm{~min}$ ), followed by a $30 \mathrm{~min}$ incubation with buffer containing a preformed avidin-biotinylated horseradish peroxidase macromolecular complex (Vectastain Elite ABC kit). Visualization of staining was achieved using a buffer containing hydrogen peroxide $(0.02 \%), \mathrm{NiCl}(0.6 \%)$, and DAB $(0.05 \%)$. Positive staining of cells was assessed by comparing staining in the presence or absence of primary antibody, viewed with phase-contrast microscopy (Olympus IMT-2). For all three cell types, staining in the absence of primary antibodies was negligible.

Determination of $b F G F$ content and release from cells. In addition to immunohistochemical detection of bFGF (see above), the presence of bFGF in glia and neurons was also verified by measuring the bFGF. like IR of cell lysates. Cells cultured for $24,48,72$, or $96 \mathrm{hr}$ were lysed with $0.1 \%$ Triton X-100 in PBS buffer, and aliquots of the lysates were assayed for FGF-like IR using RIA kitis directed against bFGF. Release of bFGF from cells was assessed by quantitating the bFGF-like IR in aliquots of media obtained from cells grown in culture for the corresponding time period, either in the presence or absence of exogenous drug(s). Thus, rclcasc of bFGF represents the cumulative release of growth factor over the indicated time course. To determine whether contaminants in the reduced-serum media would interfere with the assay, the bFGF-like IR of aliquots of nonincubated media was also measured. In these aliquots, bFGF-like IR was not detectable.

The tracer used in the kits was ${ }^{125}$ I-bFGF (bovine, recombinant), and the standards for the kits consisted of various concentrations of bovine bFGF dissolved in assay buffer (PBS). The polyclonal rabbit anti-bFGF antibody used in the kits has been previously characterized (Neufeld et al., 1987; Ferrara et al., 1988) and tested extensively. It was found to cross-react $100 \%$ with both bovine and human recombinant bFGF. Negligible cross-reactivity $(<0.01 \%)$ with other related factors, including aFGF, which exhibits greater than $50 \%$ sequence homology with 

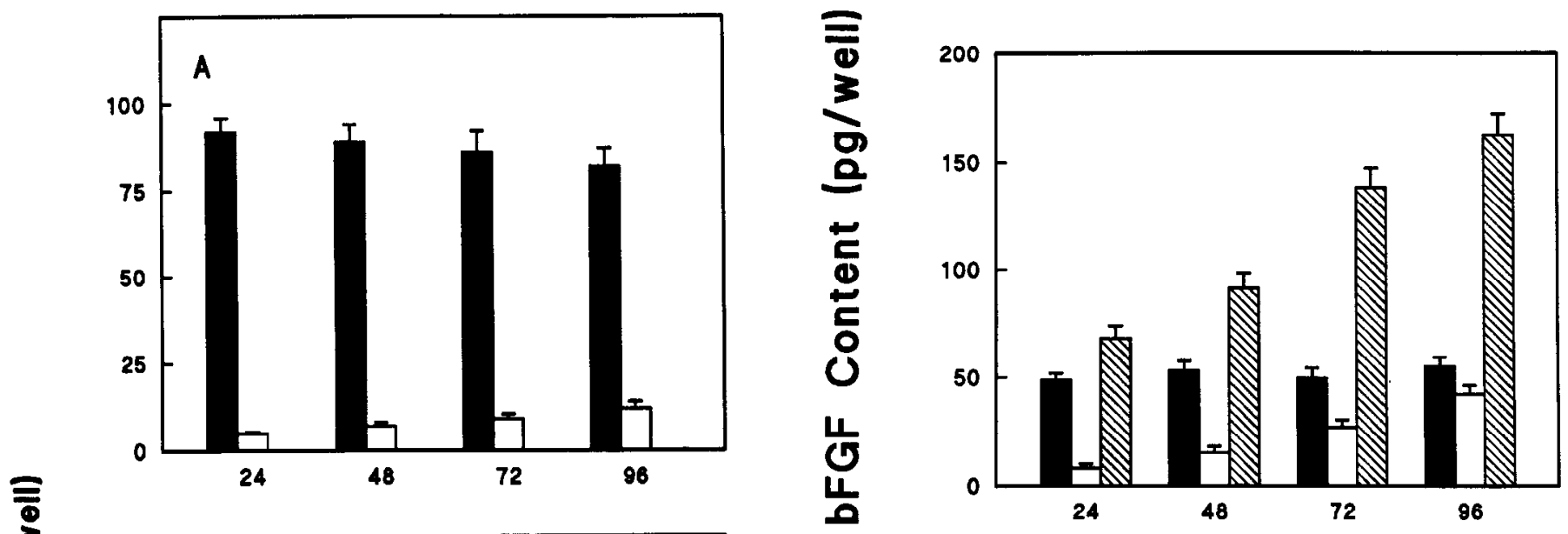

\section{Time in culture (hours)}

Figure 2. Content of bFGF in cultured glia and neurons. Cells (initial plating density, $10^{5}$ cells/well) were kept in culturc for $24,48,72$, or 96 $\mathrm{hr}$ and then detached from their wells with $1 \%$ Triton X-100 in PBS. The lysates were assayed for content of bFGF-like IR using RIA kits with antisera specific for $\mathrm{bFGF}$. bFGF content was determined for astroglia (solid bars), microglia (open bars), and hippocampal neurons (hatched bars). Results are the mean \pm SEM of 7-10 separate experiments; each sample was tested in duplicate.

bFGF (Esch et al., 1985), and interleukin-1 (IL-1), which shows approximately $30 \%$ sequence homology with bFGF (Gimenez-Gallego et al., 1985), was observed. In addition, no cross-reactivity with EGF, insulin, and cytochrome $c$ was reported (Neufeld et al., 1987). However, the antisera were also shown to cross-react significantly (>95\%) with purified N-terminally extended bFGF (Ueno et al., 1986; Moscatelli et al., 1987; Prats et al., 1989; (irothe et al., 1990) and with other forms of bFGF that have been isolated from brain (Klagsbrun et al., 1987).

Separation of antibody-bound ${ }^{125} \mathrm{I}-\mathrm{bFGF}$ and free ${ }^{125} \mathrm{I}-\mathrm{bFGF}$ was achieved using secondary donkey anti-rabbit sera coated onto magnetizable polymer particles (Amerlex M). For all assays, nonspecific binding (binding in the absence of bFGF and bFGF antisera) represented less than $15 \%$ of total counts. All experimental measures of bFGF-like IR were corrected for this.

Analysis of ${ }^{125}$ I- $b F G F$ binding sites. The total densities of ${ }^{125}$ I-bFGF sites in the three types of cell cultures were determined using full saturation analysis. Media from cells were aspirated and replaced with serum-free media containing $0.1 \%$ bovine serum albumin and various concentrations $(0.01-0.2 \mathrm{nM})$ of ${ }^{125} \mathrm{I}-\mathrm{bFGF}$ for $2 \mathrm{hr}$ at $22^{\circ} \mathrm{C}$. To remove any unbound ligand, cells were washed $(3 \times 1 \mathrm{~min})$ with ice-cold Tris ( $50 \mathrm{~mm}$ ) buffer. Finally, $100 \mu \mathrm{l}$ of $10 \%$ sodium dodecyl sulfate were added to each well to detach cells from the plastic. The resulting lysates were added to polypropylene tubes and radioactivity was quantitated. For quantitation of nonspecific binding, adjacent wells were incubated with the same concentration of ${ }^{125} \mathrm{I}-\mathrm{bFGF}$, but with excess nonradioactive bFGF (10 nM) added. Specific binding was calculated as the difference in radioactivity bound in the presence and absence of nonradioactive bFGF and represented approximately $50 \%$ of total binding at concentrations close to the $K_{d}$.

Determination of glial proliferation. The effects of exogenous bFGF on the proliferation of glial cells in vitro were assessed using the cellular incorporation of ${ }^{3} \mathrm{H}$-thymidine as an index. Astroglial or microglial cells were incubated for $24 \mathrm{hr}$ in reduced-serum (2.5-5\% FCS) media containing ${ }^{3} \mathrm{H}$-thymidine $(2 \mu \mathrm{Ci} / \mathrm{ml})$. Control cultures were incubated in the absence of exogenous bFGF, whereas test cultures (in adjacent wells) were treated with bFGF $(1-1000 \mathrm{ng} / \mathrm{ml})$. All concentrations of $b F G F$ were tested in triplicate.

Analysis of binding data. All binding data were derived from full saturation experiments. Values for $K_{d}, B_{\max }$ and $n_{\mathrm{H}}$ were obtained by computerized analysis using LIGAND by Munson and Rodbard (1980), as modified by G. A. McPherson (Elsevier Biosoft, 1985). 

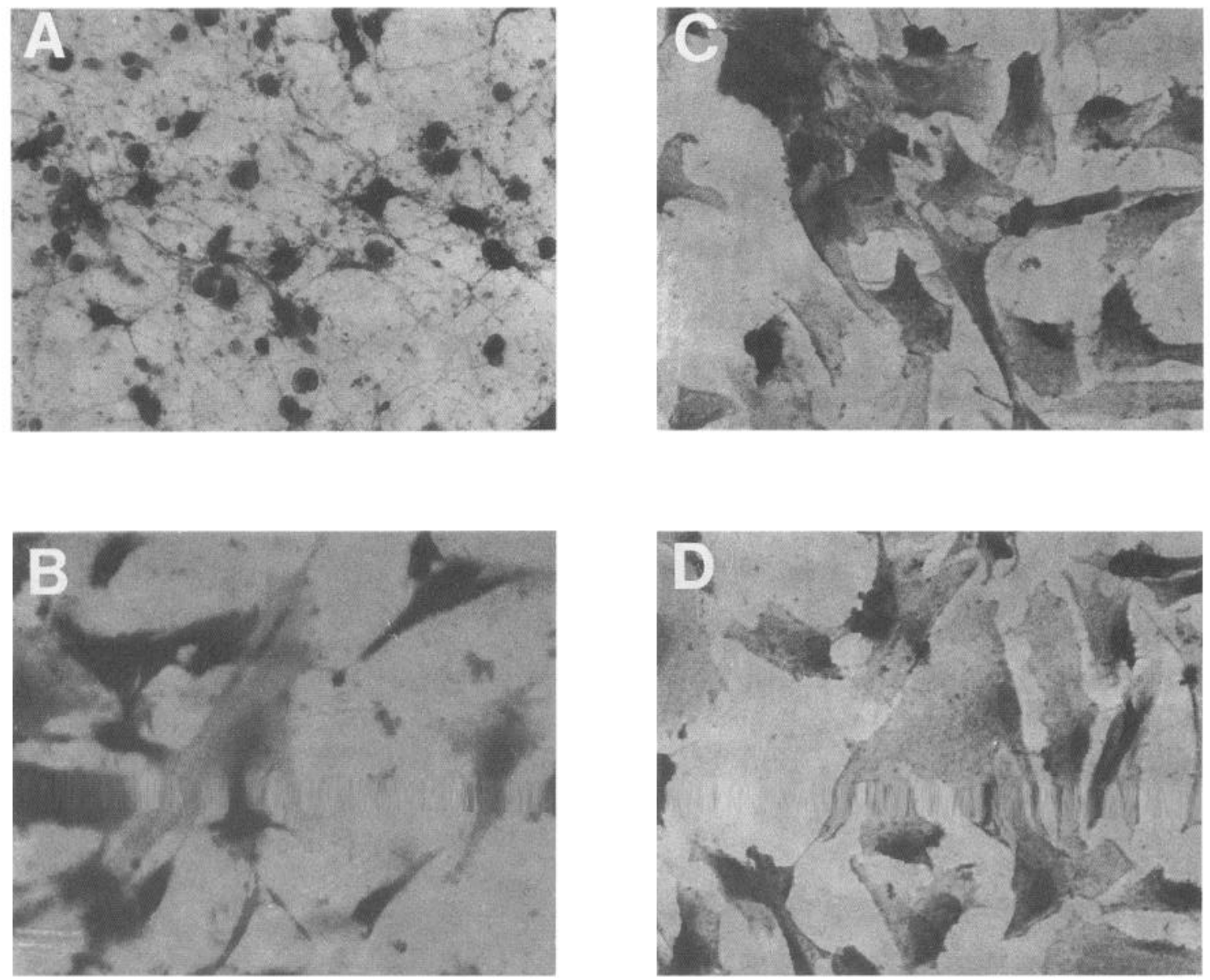

Figure 3. Immunohistochemical detection of bFGF-like IR in hippocampal neuronal $(A, B)$ and astroglial $(C, D)$ cultures. Significant staining with a monoclonal anti-bovine bFGF was evident in the $24 \mathrm{hr}$ neuronal cultures $(A)$, but in the $72 \mathrm{hr}$ cultures, staining was more intense, with many bFGF $(+)$ astroglia $(B)$ evident. In the astroglial cultures, similar numbers of bFGF $(+)$ cells were observed in the $24 \mathrm{hr}(C)$ and $72 \mathrm{hr}(D)$ cultures. Magnification, $100 \times$.

Determination of radioactivity. ${ }^{125}$ I was determined with greater than $95 \%$ efficiency in a gamma counter. ${ }^{3} \mathrm{H}$ was counted with approximately $30 \%$ efficiency using liquid scintillation spectrometry.

Statistical analyses. Results are expressed as the means \pm SEM of the indicated number of experiments. Statistical differences between control and drug treatment values were assessed first by one-way analysis of variance (ANOVA), followed by post hoc two-tailed Student's $t$ test.

\section{Results}

\section{Immunohistochemical characterization of cell cultures}

The purity of the cell cultures used in this study was assessed by staining with appropriate markers. Thus, astroglia, microglia, and neurons were identified on the basis of positive staining for GFAP, Mac-1, or NSE, respectively. For a determination of the percentage of each of the three different cell types present in the astroglial, microglial, and neuronal cultures, at various times in culture, the number of cells positive for GFAP, Mac-1, or NSE, as well as that of unstained cells, was assessed. For each different preparation, with an initial plating density of $10^{5}$ cells/well, the average number of cells positive $(+)$ for each cell marker counted in three separate wells was quantitated and expressed as a percentage of the total number of cells.

As shown in Figure 1, in the $24 \mathrm{hr}$ cultures, the majority (greater than $90 \%$ ) of cells in astroglial cultures were GFAP $(+$ ); this number was not significantly changed with increased time in culture (Fig. 1A). Moreover, only a modest number of cells, quantitated in adjacent wells, were Mac-1(+) (Fig. 1 $\mathrm{A})$. In the microglial cultures, cells were mostly Mac-1(+), but with increased time in culture, the number of $\operatorname{GFAP}(+)$ cells was markedly enhanced (Fig. $1 B$ ). In both astroglial and microglial cultures, $\mathrm{NSE}(+)$ staining was not detectable. In the $24 \mathrm{hr}$ hippocampal neuronal cultures, greater than $85 \%$ of cells were $\operatorname{NSE}(+)$ (Fig. 1C). With increased time in culture, however, the number of GFAP $(+)$ and Mac-1(+) cells increased significantly (Fig. 1C).

\section{bFGF-like IR in glia and neurons}

The presence of bFGF in glial and neuronal cultures was first determined using RIA detection of bFGF-like IR in cell lysates from $24,48,72$, or $96 \mathrm{hr}$ cultures. In astroglial cultures, bFGF content of cells was similar regardless of time in culture (Fig. 2). In microglial cultures, levels of bFGF-like IR were considerably lower than those measured for the astroglial cultures, for the corresponding time point (Fig. 2). Only by $96 \mathrm{hr}$ in culture were the levels of bFGF-like IR in microglia comparable to those of astroglia (Fig. 2).

In hippocampal neurons, bFGF-like IR in the $24 \mathrm{hr}$ cultures was not significantly different from that of astroglia (Fig. 2). However, neuronal bFGF-like IR appeared to increase with time in culture, such that the levels in the 72 and $96 \mathrm{hr}$ cultures were significantly higher than in the astroglial cultures (Fig. 2). However, because the number of GFAP $(+)$ cells (range, 25$35 \%$ of the total cell number) in these cultures was significantly 

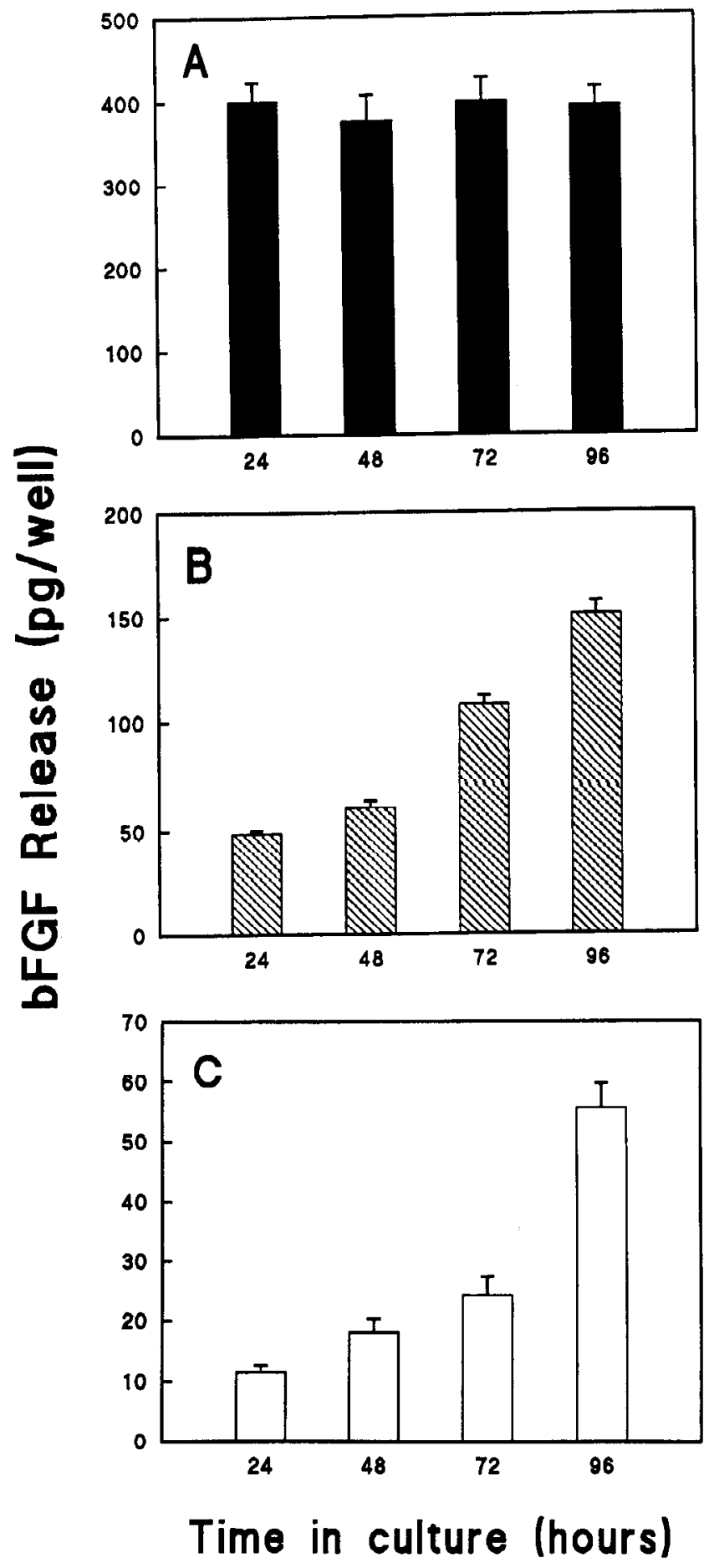

Figure 4. Time-dependent release of bFGF from cell cultures. Cells were initially plated at a density of $10^{5}$ cells/well and were kept in DMEM/reduced-serum media for $24,48,72$, or $96 \mathrm{hr}$. Media were then collected for determination of bFGF-like IR (i.e., bFGF release). The cumulative release from astroglia $(A)$, microglia $(B)$, and hippocampal neurons $(C)$ was assessed. Results are thc mcan \pm SEM of 7-12 scparatc experiments, where each sample was tested in duplicate.

higher than in the $24 \mathrm{hr}$ cultures, it seems likely that the increased bFGF content simply reflected an increased proliferation in $\mathrm{bFGF}(+)$ astroglia. This was confirmed by the immunohistochemical data: there was significant bFGF-like staining in the $24 \mathrm{hr}$ neuronal cultures (Fig. $3 \mathrm{~A}$ ), but by $72 \mathrm{hr}$ in culture many heavily stained and some more lightly stained $\mathrm{bFGF}(+)$ astroglia were apparent in these cultures (Fig. 3B). In contrast, bFGF staining in astroglia was similar in the $24 \mathrm{hr}$ (Fig. 3C) and $72 \mathrm{hr}$ (Fig. $3 \mathrm{D}$ ) cultures. Thus, both methods of detecting cellular bFGF-like IR indicate that bFGF is present in both glial and neuronal cells in culture.

\section{Time course of $b F G F$ release from glia and neurons in vitro}

To determine whether bFGF present in glia and neurons (see above) can be released from these cells, the media content of bFGF-like IR was measured. The levels of bFGF present in astroglial media were markedly higher than the measured cell content (Figs. 2, 4A). In these cells, significant levels of released bFGF (range, 398-440 pg/well) were detected in the $24 \mathrm{hr}$ cultures (Fig. $4 A$ ). This release did not appear to increase with prolonged time in culture; release in the 48, 72, and $96 \mathrm{hr}$ cultures was similar to that in the $24 \mathrm{hr}$ cultures (Fig. $4 A$ ). Therefore, it appears that in these cultures, a constant basal level of bFGF is released into the media.

In contrast to astroglial cultures, release of bFGF from microglial cells appeared to increase with time in culture (Fig. $4 B$ ). Release in the 72 and $96 \mathrm{hr}$ cultures was significantly different (increased by 129-225\%) from that in either the 24 or $48 \mathrm{hr}$ cultures $(P<0.01)$. However, the levels of bFGF released from microglia (range, $47-87 \mathrm{pg} /$ well) were significantly lower than those measured in the astroglial cultures (Figs. $4 A, B$ ).

In hippocampal neuronal cultures, release of bFGF was less than that observed for either microglial or astroglial cultures (Fig. $4 C$ ). bFGF release in the $24 \mathrm{hr}$ cultures was less than $0.1 \%$ that released by astrocytes for the corresponding time period (Fig. 4A,C). As shown for microglial cultures (Fig. 4B), bFGF release from hippocampal neurons was significantly higher $(P$ $<0.001$ ) in the $96 \mathrm{hr}$ cultures compared to the $24 \mathrm{hr}$ cultures (Fig. 4C).

\section{Effects of various lymphokines and trophic factors on the release of $b F G F$ from glial cells in vitro}

The following experiments were undertaken to determine whether glial-derived trophic factors and lymphokines alter the release of bFGF from glial cells. Various trophic factors and lymphokines that are known to be released from glial cells (see reviews by Hefti et al., 1989; Walicke, 1989; Araujo et al., 1990; Carpenter and Cohen, 1990) can stimulate the proliferation of astroglial and microglial cells in vitro and in vivo. For example, IL-1 $\beta$, which shares a significant degree of sequence homology with bFGF (Gimenez-Gallego et al., 1985), is released from microglia and acts as a mitogen for astroglia in vitro and in vivo (Giulian and Baker, 1986; Giulian, 1987; Giulian et al., 1988). However, little is currently known about whether lymphokines and trophic factors can elicit or inhibit the release of growth factors such as bFGF from CNS cells.

Our results show that the release of bFGF from astroglial cells was significantly enhanced by specific lymphokines (Fig. $5 A$ ). The most potent stimulator of bFGF release from astroglia was IL- $1 \beta$; with concentrations as low as $1 \mathrm{ng} / \mathrm{ml}$, the lymphokine enhanced release by $53.3 \pm 15.1 \%$ compared to control cultures. With IL-6, there was an increase in bFGF release from astroglia, but the magnitude of this effect was small in comparison to that of IL-1 $\beta$ (Fig. 5A). IL-3 and IFN did not significantly affect bFGF release (Fig. 5A). Other lymphokines tested (IL-2, IL-4, IL-7, and IL-8) also did not alter bFGF release from either 

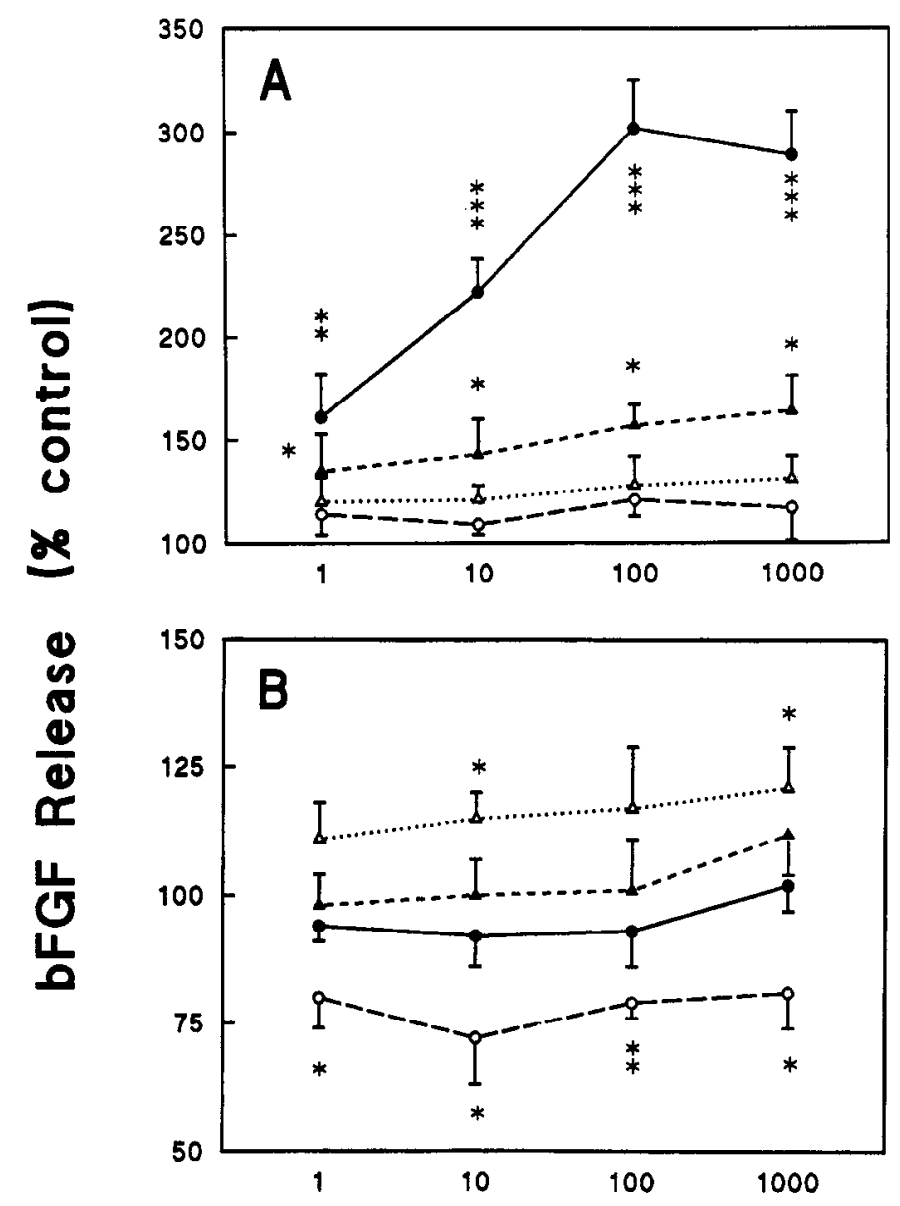

\section{Lymphokine (ng/ml)}

Figure 5. Effects of lymphokines on the release of bFGF from glial cells in vitro. Astroglia $(A)$ and microglia $(B)$ were cultured in reducedserum $(2.5 \%)$ media for $24 \mathrm{hr}$ in the presence or absence (control) of the indicated concentrations of IL-1 (solid line, solid circles), IL-3 (dashed line, open circles), IL-6 (dashed line, solid triangles), or IFN (dotted line, open triangles). Results are the mean \pm SEM of five to seven experiments. ${ }^{*}, P<0.05$; $^{* *}, P<0.01 ;{ }^{* * *}, P<0.001$.

astroglia or microglia; release ranged from $99.3 \pm 5.8 \%$ to 109.7 $\pm 8.6 \%$ of control.

In microglial cell cultures, release of bFGF was not markedly altered by either IL- $1 \beta$ or IL- 6 (Fig. $5 B$ ). With IFN, only slight increases (range, 4.1-37.3\%) in bFGF release were observed (Fig. $5 B$ ). In contrast, small but significant reductions in bFGF release from microglia were noted in the presence of IL-3 (Fig. $5 B$ ). This effect was apparent with concentrations of IL-3 as low as $1 \mathrm{ng} / \mathrm{ml}$ (Fig. $5 B$ ).

The more "classical" growth factors EGF and NGF are known to be released from glial cells and to stimulate astroglial proliferation (Furukawa et al., 1987; Houlgatte et al., 1989; Yoshida and Gage, 1991; see also reviews by Johnson and Taniuchi, 1987; Carpenter and Cohen, 1990). In the present experiments, both were tested for their effects on bFGF release from glial cultures (Fig. 6). In astroglial cultures, release of bFGF was considerably enhanced by EGF, with all concentrations tested (Fig. 6A). In contrast, significant effects of NGF on bFGF release from astroglia were not readily apparent (Fig. $6 A$ ).
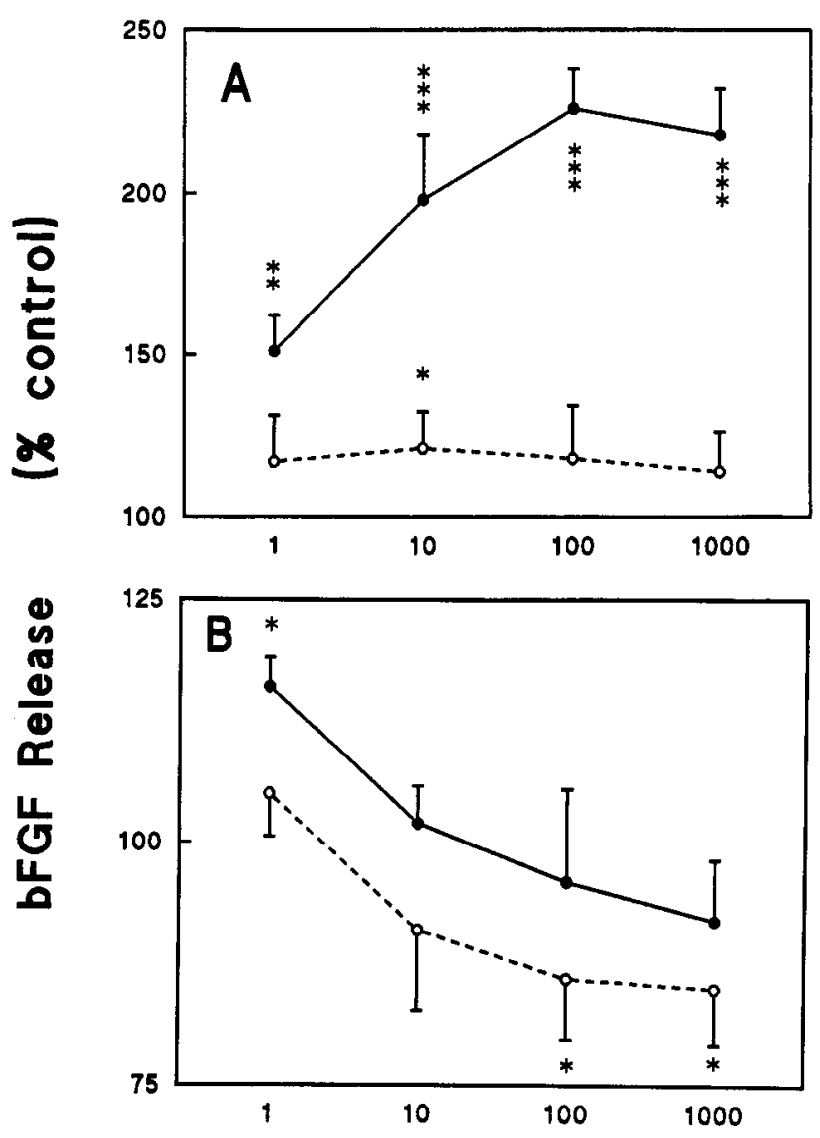

\section{Growth Factor (ng/ml)}

Figure 6. Effects of EGF and NGF on bFGF release from glial cells in vitro. Astroglia $(A)$ and microglia $(B)$ were cultured in reduced-serum media in the presence or absence (control) of the indicated concentrations of EGF (solid line) or NGF (dashed line). Results are the mean \pm SEM of five experiments. ${ }^{*}, P<0.05 ;{ }^{* *}, P<0.01 ;{ }^{* *}, P<0.001$.

In microglial cultures, release of bFGF was slightly increased by $1 \mathrm{ng} / \mathrm{ml} \mathrm{EGF}$ (Fig. $6 B$ ). With higher concentrations of the growth factor, there was a trend for decreased release of $b F G F$, although this did not reach statistical significance (Fig. 6B). NGF $(100-1000 \mathrm{ng} / \mathrm{ml})$, in contrast, significantly reduced bFGF release (Fig. 6B).

In hippocampal neuronal cultures, release of bFGF was not altered by any of the lymphokines or trophic factors tested. In all cases, release in the presence of drug(s) was not different from that in its absence and ranged between $91 \%$ and $110 \%$ of control.

\section{${ }^{125} I-b F G F$ binding sites}

To determine whether binding sites specific for bFGF are present on glial or neuronal cells in vitro, the binding of ${ }^{125}$ I-bFGF to these cells was assessed. Preliminary experiments tested the saturability of ${ }^{125}$ I-bFGF binding to cells in vitro; saturation was reached within 1-2 hr, with concentrations of free ligand close to $150 \mathrm{pm}$, for astroglial and neuronal cells (Fig. $7 A$ ). For microglia, saturation of sites was evident with concentrations of ${ }^{125} \mathrm{I}-\mathrm{bFGF}$ as low as $50 \mathrm{pM}$ (Fig. $7 \mathrm{~A}$ ).

Using the experimental conditions described, ${ }^{125}$ I-bFGF was found to bind saturably, specifically, with limited capacity $\left(B_{\max }\right)$ and high affinity $\left(K_{d}\right)$ to a single class $\left(n_{\mathrm{H}}\right.$ close to 1.0$)$ of bFGF 

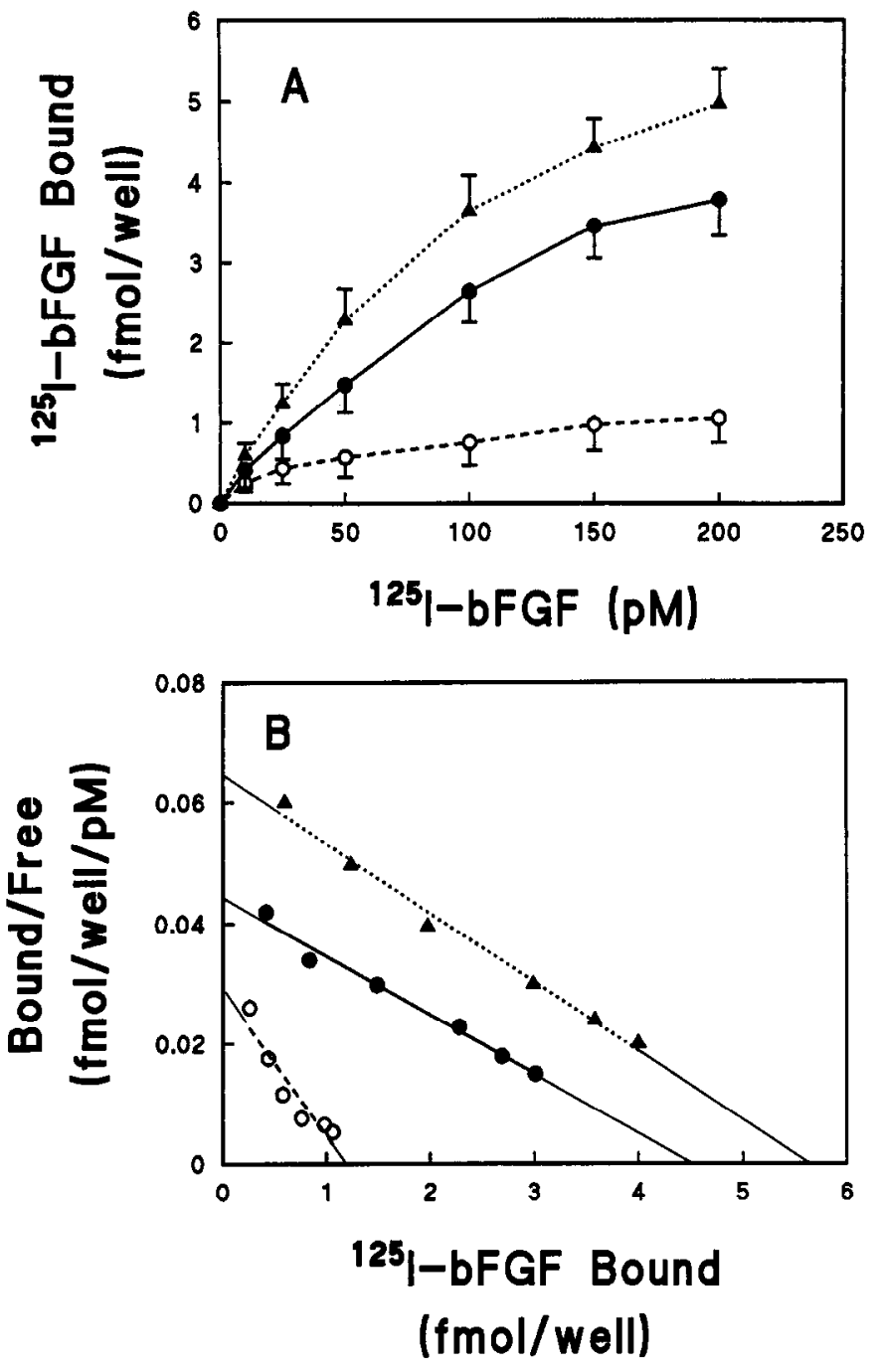

Figure 7. Characterization of ${ }^{125}$ I-bFGF binding to glial and neuronal cells in vitro: full saturation analysis of ${ }^{125} \mathrm{I}-\mathrm{bFGF}$ binding $(A)$ to astroglia (solid line), microglia (dashed line), and hippocampal neurons (dotted line). In $B$, the Scatchard plot of the full saturation analysis is depicted. Cells $\left(2 \times 10^{5}\right.$ cells/well) were incubated $\left(22^{\circ} \mathrm{C}, 2 \mathrm{hr}\right)$ in DMEM/F-12 media without FCS, but with $0.1 \%$ bovine serum albumin and the indicated concentrations of ${ }^{125}$ I-bFGF. Nonspecific binding was assessed by incubating adjacent wells with the same concentration of ${ }^{125}$ I-bFGF, but with excess (10 nM) nonradioactive bFGF. Results are the mean \pm SEM of four separate experiments, where each concentration of ligand was tested in triplicate.

binding sites (Fig. 7, Table 1) on all three cell types studied. The highest density of sites was apparent in hippocampal neuronal cultures, whereas the lowest was found in microglial cells (Fig. $7 A$, Table 1).

Scatchard analysis of the saturation data of ${ }^{125} \mathrm{I}-\mathrm{bFGF}$ binding to cells in vitro further illustrated that bFGF bound to a single class of high-affinity receptor sites in all three cell culture types (Fig. $7 B$ ). Whereas the $K_{d}$ for astroglia and hippocampal neurons was similar, that for microglia was significantly lower (Table 1, Fig. 7B).

\section{Effects of exogenous bFGF on glial cell proliferation}

In an attempt to determine whether the high-affinity bFGF receptor sites localized to glia (see above) represent functional receptors, we tested the mitogenic effects of exogenous bFGF
Table 1. Parameters of ${ }^{125}$ I-bFGF binding to glial and neuronal cells in vitro

\begin{tabular}{llll} 
& \multicolumn{4}{l}{ 125I-bFGF binding } \\
\cline { 2 - 4 } & $B_{\max }$ & $K_{d}$ & $n_{\mathrm{H}}$ \\
\hline Astroglia & $4.24 \pm 0.45$ & $79.0 \pm 8.6$ & $1.02 \pm 0.26$ \\
Microglia & $1.36 \pm 0.31$ & $35.8 \pm 5.9$ & $0.95 \pm 0.19$ \\
Hippocampal neurons & $5.39 \pm 0.43$ & $83.2 \pm 9.4$ & $1.11 \pm 0.24$
\end{tabular}

Binding data were derived from full saturation analysis. Cells were incubated as described in Materials and Methods, with various concentrations of ${ }^{125} \mathrm{I}-\mathrm{bFGF}$ (0.01-200 pM) for $2 \mathrm{hr}$ at $22^{\circ} \mathrm{C}$. $B_{\max }$ is the apparent maximal binding capacity (fmol $/ 10^{s}$ cells), $K_{d}$ is the apparent affinity of binding (pM), and $n_{\mathrm{H}}$ is the Hill coefficient. Values are the mean \pm SEM of four separate experiments, where each concentration of ligand was tested in triplicate. Nonspecific binding was assessed in the presence of excess (10 nM) nonradioactive bFGF.

on glial cultures. Toward this end, the effects of bFGF on glial proliferation were evaluated, by comparing the incorporation of ${ }^{3} \mathrm{H}$-thymidine into control cells with that of cells treated with bFGF $(1-1000 \mathrm{ng} / \mathrm{ml})$ for $24 \mathrm{hr}$.

In astroglial cultures, ${ }^{3} \mathrm{H}$-thymidine uptake into cells was significantly augmented by even the lowest concentration (1 ng/ $\mathrm{ml}$ ) of bFGF tested, with maximal increases observed with 1 $\mu \mathrm{g} / \mathrm{ml}$ of bFGF (range, 19-63\% increase over control). In contrast, the effects of bFGF on ${ }^{3} \mathrm{H}$-thymidine incorporation into microglial cells were slight (range, $4-18 \%$ increase over control).

\section{Discussion}

The main finding of the present study is that bFGF is released from astroglial, microglial, and neuronal cells in vitro. Thus, although bFGF lacks a distinct signal sequence (Esch et al., 1985; Abraham et al., 1986; Thomas, 1987), it is evident that the peptide is released from CNS cells, albeit by an as yet uncharacterized mechanism. Moreover, the detection of high-affinity bFGF receptor sites on glia and neurons suggests that endogenous bFGF released from glia, and to a lesser extent from neurons, may have physiological significance, perhaps in the maintenance of CNS function.

\section{bFGF content and release in glia and neurons in vitro}

The present results confirm and extend earlier findings that bFGF is present in cells of glial (Pettmann et al., 1986) and neuronal (Ferrara et al., 1988; Hatten et al., 1988) origin. Glial content of bFGF appeared to be lower than that of hippocampal neurons, particularly if the 72 and $96 \mathrm{hr}$ neuronal cultures are considered. However, in neurons, the increased content of bFGF with time in culture was likely due to proliferating glial cells, rather than to increased synthesis of bFGF by neurons. This is supported by the immunohistochemical data showing that in the 72 and $96 \mathrm{hr}$ neuronal cultures, the number of $\mathrm{bFGF}(+)$ astroglia [i.e., GFAP(+) cells] reached significant levels. Thus, the results from immunohistochemical and RIA experiments clearly show that bFGF is present in CNS cells of glial and neuronal origin in vitro.

Previous studies have speculated that bFGF might be released from cells by a nonclassical mechanism (Vlodavsky et al., 1987; Flaumenhaft et al., 1990; Saksela and Rifkin, 1990; Tsuboi et al., 1990). Indeed, release of active bFGF-heparan sulfate complexes from the extracellular matrix of endothelial cclls by stimulation of proteolytic activity has been reported (Vlodavsky et al., 1987; Saksela and Rifkin, 1990). However, it is not clear whether a similar mechanism applies to CNS cells. Our results 
clearly indicate that bFGF-like peptides are released from both glial and neuronal cells in vitro. The high ratio of released bFGFlike IR to cellular bFGF-like IR in astroglia suggests that a constant basal level of the bFGF-like IR contained in these cells is released. Furthermore, the finding that similar levels of bFGFlike IR are present in astroglial media regardless of time in culture suggests that steady levels of external bFGF may be required to maintain these cells in culture. Nevertheless, the mechanism whereby bFGF is released from the cultures described in this study remains to be elucidated. However, it appears that depolarization of these cells, such as by increasing the $\mathrm{K}^{+}$and $\mathrm{Ca}^{2+}$ in the media, does not alter bFGF release. Thus, bFGF release from neuronal or glial cultures incubated for a short period ( 1 or $2 \mathrm{hr}$ ) with high- $\mathrm{K}^{+}(25$ or $50 \mathrm{~mm})$ or high- $\mathrm{Ca}^{2+}(5 \mathrm{~mm})$ media ranged from $95.4 \%$ to $105.6 \%$ of control.

It is important to note that because our assay procedure may detect other isoforms (Klagsbrun et al., 1987) or N-terminally extended forms of bFGF (Esch et al., 1985; Ueno et al., 1986; Moscatclli ct al., 1987; Prats et al., 1989; Grothe et al., 1990), the precise nature of the bFGF IR detected in the cell media remains to be elucidated. Nevertheless, the results emphasize that glia, and to a lesser extent neurons, are capable of releasing some bFGF-like molecule. Moreover, the data are consistent with the hypothesis that bFGF may function as an autocrine factor for astroglia, as has been suggested for other cell types (Okumura et al., 1989; Saksela and Rifkin, 1990), at least in vitro. However, the conditions under which bFGF is released from glial cells have not yet been fully characterized.

Initially, it was suggested that bFGF is released from glia only during episodes of CNS injury or glial cell death (Baird and Ling, 1987). Contrary to this, a preliminary report by Rifkin (1991) clearly demonstrated that a single, viable astrocyte was capable of releasing bFGF. In our study, the possibility that some type of cellular damage is solely responsible for astroglial bFGF relcase is also unlikely. First, the experiments demonstrating that astroglia were responsive to stimulation of bFGF release by some growth factors, but not others, would argue against the existence of any significant injury to these cells. Second, release of bFGF in the $96 \mathrm{hr}$ cultures, which are presumably less healthy than the $24 \mathrm{hr}$ cultures, was the same as that in the $24 \mathrm{hr}$ cultures. Third, the astroglia ( $24 \mathrm{hr}$ cultures) responded to exogenuus bFGF in a concentration-dependent manner, as has been reported by other investigators (Pruss et al., 1982; Pettmann et al., 1985), suggesting that cellular damage was unlikely.

The relatively low levels of bFGF released by microglia, and especially by hippocampal neurons, are indicative of a different function for bFGF in these cells. Even though bFGF may not be an autocrine factor for neurons, the probability that astroglial-derived bFGF may affect these cells is not inconsistent with our results. Indeed, a role for glial-derived bFGF in promoting neurite extension has been recently proposed (Hatten et al., 1988). However, since astroglial maturation occurs later than that of neurons (Fujita, 1963), the contribution of glial-derived bFGF in CNS development, as well as the stage of development involved, is not completely understood. However, it is possible that glial-derived bFGF may be involved in the neuronal degeneration that accompanies some pathologies of the CNS, whether by promoting neurite sprouting or by exacerbating the pathological insult. Thus, bFGF has been implicated in the prevention of neuronal death following experimental lesions (An- derson et al., 1988; Otto et al., 1989; Otto and Unsicker, 1990), as well as the induction of neurite sprouting that leads to plaque formation in Alzheimer's disease (Gomez-Pinilla et al., 1990; Stopa et al., 1990).

\section{Alteration of $b F G F$ release by lymphokines and other growth factors}

A variety of lymphokines that are known to be released from astroglia and microglia can affect the function of glial cells. IL1 , which is released from microglia (Giulian and Baker, 1985, 1986; Giulian and Lachman, 1985; Giulian, 1987; Giulian et al., 1988) stimulates astroglial proliferation both in vitro and in vivo. Conversely, IL-3 released from astroglia is a growth factor for microglia (Frei and Fontana, 1986). Therefore, the question of whether these lymphokines and related factors result in concomitant changes in bFGF release from glial cells was addressed.

Of the lymphokines tested, the most potent stimulator of bFGF release from astroglial cells was IL-1. The modest (IL-6) or lack of effect of other lymphokines suggests that the IL-1induced increase in astroglial bFGF release is mediated by specific IL- 1 receptors and is not the result of nonspecific membrane effects that have been reported for some lymphokines (see review by Araujo et al., 1990). Since IL-1 is known to stimulate the proliferation of astroglia (Giulian and Baker, 1985; Giulian and Lachman, 1985; Giulian, 1987; Giulian et al., 1988), it is possible that the increased bFGF release mediated by IL- 1 is simply a consequence of increased cell number. Although this possibility cannot be completely excluded, it seems unlikely since the effect on bFGF release was of much greater magnitude and apparent with lower concentrations of IL-1 than that shown for astroglial proliferation (Giulian and Baker, 1985; Giulian, 1987; D. M. Araujo and C. W. Cotman, unpublished observations).

In microglial cultures, the effects of lymphokines were modest, but both increases and reductions in bFGF release were evident. The augmentcd rclease in microglia treated with IFN was significantly less than the reported mitogenic effect of the peptide on microglia (see Araujo et al., 1990). Curiously, IL-3, a lymphokine that is known to stimulate the proliferation of these cells (Frei and Fontana, 1986), resulted in a small reduction in bFGF release. Although the significance of these effects are not yet apparent, the results suggest that regulation of bFGF release from microglia is not of critical importance in the maintenance of these cells in vitro. Our results demonstrating that exogenous bFGF did not significantly affect microglial proliferation are consistent with this view. However, in pathological conditions, such as CNS trauma or neurological disease, where there is a proliferation of microglia (see review by Giulian, 1987) and a subsequent increase in lymphokines and neurotrophic factors surrounding "lesion" sites, regulation of microglial bFGF release by lymphokines may become of consequence. Furthermore, the increased release of IL-1 by thesc proliferating microglia may enhance astroglial production of bFGF, which further stimulates astroglial proliferation. In Alzheimer's disease, this increase in glial bFGF around senile plaques (Gomez-Pinilla et al., 1990; Stopa et al., 1990) has been implicated in the induction of amyloid synthesis (Quon et al., 1990) and subsequent plaque development.

In glia treated with EGF, contrasting effects on bFGF release from microglia and astrocytes were apparent. EGF markedly increased astroglial bFGF release, even with the lowest concentration tested $(1 \mathrm{ng} / \mathrm{ml})$. This appears to be mainly a direct 
consequence of stimulated bFGF secretory mechanisms, rather than an indirect result of increased astroglial proliferation, because the large increase induced by EGF exceeded the reported effect of EGF on astroglial proliferation (see Carpenter and Cohen, 1990). In microglia, release was modestly enhanced by 1 $\mathrm{ng} / \mathrm{ml}$, but was not significantly altered with higher concentrations of EGF. This further substantiates the hypothesis proposed above that under normal circumstances, regulation of $\mathrm{bFGF}$ release from microglia by growth factors is not crucial.

Unlike EGF, NGF did not alter bFGF release from astroglia, indicating that although glia are capable of releasing NGF (Furukawa et al., 1987; Houlgatte et al., 1989; Ono et al., 1991; Yoshida and Gage, 1991), these cells appear not to be responsive to released NGF. This result is in agreement with data showing that high-affinity NGF receptors are not present on astroglia (Johnson and Taniuchi, 1987). In contrast, NGF reduced bFGF release from microglia, but only with concentrations (100-1000 $\mathrm{ng} / \mathrm{ml}$ ) that were significantly higher than required for neurotrophic effects (see reviews by Hefti et al., 1989; Lapchak and Hefti, 1991). Thus, although the main function of NGF rclcascd from glia in vivo may be as a trophic and maintenance factor for CNS neurons (Hefti et al., 1989; Lapchak and Hefti, 1991), the intriguing possibility remains that glial NGF may, in addition, modulate microglial activity.

\section{Glial and neuronal bFGF binding sites}

In vitro studies using endothelial cells have provided some understanding of the complex nature of bFGF binding to its highaffinity receptor and to low-affinity heparin-like substances and other glycosaminoglycans (GAGs) (Moscatelli, 1987, 1988). In the present study, the kinetics of ${ }^{125}$ I-bFGF binding, including time course of saturation, $B_{\max }$, and $K_{d}$, resemble those described previously for hippocampal neurons (Walicke, $1988 \mathrm{~b}$; Walicke et al., 1989). In the latter studies, minimal binding of bFGF to GAGs was demonstrated. Thus, although ${ }^{125} \mathrm{I}-\mathrm{bFGF}$ binding to GAGs cannot be completely excluded in our study, the results strongly suggest that the ${ }^{125} \mathrm{I}-\mathrm{bFGF}$ sites in our cultures represent functional bFGF receptors. In this respect, these cells differ from mesenchymal cells, in which greater than $90 \%$ of ${ }^{125}$ I-bFGF binding sites are the result of low-affinity binding to GAGs (Moscatelli, 1987, 1988).

The physiological significance of bFGF receptors on neurons is unequivocal. In these cells effects of bFGF on cell survival (Walicke et al., 1986; Walicke, 1988a; Walicke and Baird, 1988; Matsuda et al., 1990) and neurite extension (Hatten et al., 1988; Walicke, 1988a,b), which must be mediated by bFGF receptors, have been extensively reported (see also reviews by Baird and Walicke, 1989; Walicke, 1989). Similarly, our finding that highaffinity bFGF receptors are present in astroglial cultures was not unexpected since effects of bFGF on astroglial proliferation have been demonstrated (Morrison and de Vellis, 1981; Pruss et al., 1982; Pettmann et al., 1985). In addition, we show that bFGF promotes astroglial proliferation with physiologically pertinent concentrations of the peptide (see reviews by Baird and Walicke, 1989; Walicke, 1989).

The present study also shows that high-affinity bFGF sites can be detected in microglia in vitro, but the importance of these sites remains to be elucidated. Unlike astroglia, proliferation of microglia was only modestly enhanced by bFGF. In addition, the phagocytic properties of microglia are known to be unaffected by bFGF (Giulian and Ingeman, 1988). This is unlikely to be attributable to an overall restriction in the responsiveness of these cells to growth factors, since a variety of these factors have been shown to stimulate microglial proliferation (Frei and Fontana, 1986; Giulian, 1987; Giulian and Ingeman, 1988). It is possible that microglial bFGF receptor sites may be of some significance in vivo, although the conditions under which they may become functional and, indeed, whether these sites are expressed at all in vivo have yet to be investigated.

In summary, our results present the first complete evidence that a bFGF-like molecule is localized to and released from astroglia, microglia, and hippocampal neurons. Moreover, glial bFGF release is differentially regulated by a variety of lymphokines and trophic factors. This suggests that conditions under which an imbalance of these molecules occur, such as in CNS trauma or disease, may adversely affect bFGF production by these cells and set forth a cascade of events that may aggravate the initial insult. In addition, the demonstration that specific bFGF receptor sites are also present on these cells implies that endogenous bFGF released from glia and neurons may have diverse functions in the CNS.

\section{References}

Abraham JA, Mergia A, Whang JL, Tumolo A, Friedman J, Hjerrild KA, Gospodarowicz D, Fiddes JC (1986) Nucleotide sequence of a bovine clone encoding the angiogenic protein, basic fibroblast growth factor. Science 233:545-548.

Anderson KJ, Dam D, Lee S, Cotman CW (1988) Basic fibroblast growth factor prevents death of lesioned cholinergic neurons in vivo. Nature 232:360-361.

Araujo DM, Chabot JG, Quirion R (1990) Potential neurotrophic factors in the mammalian central nervous system: functional significance in the developing and aging brain. Int Rev Neurobiol 32:141174.

Baird A, Ling N (1987) Fibroblast growth factors are present in the cxtraccllular matrix produced by endothelial cells in vitro: implications for a role of heparinase-like enzymes in the neovascular response. Biochem Biophys Res Commun 142:428-435.

Baird A, Walicke PA (1989) Fibroblast growth factors. Br Med Bull 45:438-452.

Baird A, Esch F, Mormede P, Ueno N, Ling N, Bohlen P, Ying S, Wehrenberg W, Guillemin R (1986) Molecular characterization of fibroblast growth factor: distribution and biological activities in various tissues. Recent Prog Horm Res 42:143-152.

Carpenter G, Cohen S (1990) Epidermal growth factor. J Biol Chem 265:7709-7712.

Esch F, Baird A, Ling N, Ueno N, Hill F, Denoroy L, Klepper R, Gospodarowicz D, Bohlen P, Guillemin R (1985) Primary structure of bovine pituitary basic fibroblast growth factor (FGF) and comparison with the amino-terminal sequence of bovine brain acidic FGF. Proc Natl Acad Sci USA 82:6507-6511.

Ferguson IA, Schweitzer JB, Johnson EM Jr (1990) Basic fibroblast growth factor: receptor-mediated internalization, metabolism, and anterograde axonal transport in retinal ganglion cells. J Neurosci 10: 2176-2189.

Ferrara N, Ousley F, Gospodarowicz D (1988) Bovine brain astrocytes express basic fibroblast growth factor, a neurotrophic and angiogenic mitogen. Brain Res 462:223-232.

Ferrari G, Minozzi MC, Toffano G, Leon A, Skaper SD (1989) Basic fibroblast growth factor promotes the survival and development of mesencephalic neurons in culture. Dev Biol 133:140-147.

Flaumenhaft R, Moscatelli D, Rifkin DB (1990) Heparin and heparan sulfate increase the radius of diffusion and action of basic fibroblast growth factor. J Cell Biol 111:1651-1659.

Frei K, Fontana A (1986) Astrocyte-derived IL-3 as a growth factor for microglia and peritoneal macrophages. J Immunol 1 1:3521-3527.

Fujita S (1963) The matrix cell and cytogenesis in the developing central nervous system. J Comp Neurol 120:37-42.

Furukawa SH, Furukawa Y, Stayoshi E, Hayashi K (1987) Synthesis/ secretion of nerve growth factor is associated with cell growth in 
cultured mouse astroglial cells. Biochem Biophys Res Commun 142: $395-402$.

Gimenez-Gallego G, Rodkey J, Bennett C, Rios-Candelore M, DiSalvo J, Thomas K (1985) Brain-derived acidic fibroblast growth factor: complete amino acid sequence and homologies. Science 230:13851388 .

Giulian D (1987) Amoeboid microglia as effectors of inflammation in the central nervous system. J Neurosci Res 18:155-171.

Giulian D, Baker TJ (1985) Peptides released by amoeboid microglia regulate astroglial proliferation. J Cell Biol 101:2411-2415.

Giulian D, Baker TJ (1986) Characterization of amoeboid microglia isolated from developing mammalian brain. J Neurosci 6:2163-2178.

Giulian D, Ingeman JE (1988) Colony-stimulating factors as promoters of amoeboid microglia. J Neurosci 8:4707-4717.

Giulian D, Lachman LB (1985) Interleukin-1 stimulates astroglial proliferation after brain injury. Science 228:497-499.

Giulian D, Woodward J, Young DJ, Krebs F, Lachman LB (1988) Interleukin-1 injected into mammalian brain stimulates astrogliosis and neovascularization. J Neurosci 8:2485-2490.

Gomez-Pinilla F, Cummings BJ, Cotman CW (1990) Induction of basic fibroblast growth factor in Alzheimer's disease pathology. Neuroreport 1:211-214.

Gospodarowicz D, Neufeld G, Schweigerer L (1986) Fibroblast growth factor. Mol Cell Endocrinol 46:187-206.

Gospodarowicz D, Ferrara N, Schweigerer L, Neufeld G (1987) Structural characterization and biological functions of fibroblast growth factor. Endocrinol Rev 8:95-114.

Grothe C, Zachmann K, Unsicker K, Westermann R (1990) High molecular weight forms of basic fibroblast growth factor recognized by a new anti-bFGF antibody. FEBS Lett 260:35-38.

Hatten ME, Lynch M, Rydel RE, Sanchez J, Joseph-Siverstein J, Moscatelli D, Rifkin DB (1988) In vitro neurite extension by granule neurons is dependent upon astroglial-derived fibroblast growth factor. Dev Biol 125:280-289.

Hefti F, Hartikka J, Knusel B (1989) Function of neurotrophic factors in the adult and aging brain and their possible use in the treatment of neurodegenerative diseases. Neurobiol Aging 10:515-533.

Houlgatte R, Mallat M, Brachet P, Prochiantz A (1989) Secretion of nerve growth factor in culture of glial cells and neurons derived from different regions of the mouse brain. J Neurosci Res 24:143-152.

Johnson EM, Taniuchi M (1987) Nerve growth factor (NGF) receptors in the central nervous system. Biochem Pharmacol 36:4189-4195.

Jordan FL, Thomas WE (1987) Identification of microglia in primary cultures of mixed cerebral cortical cells. Brain Res Bull 19:153-159.

Klagsbrun M, Smith S, Sullivan R, Shing Y, Davidson S, Smith JA, Sasse J (1987) Multiple forms of basic fibroblast growth factor: amino-terminal cleavages by tumor cell- and brain cell-derived acid proteinases. Proc Natl Acad Sci USA 84:1839-1843.

Knusel B, Michel PP, Schwaber JS, Hefti F (1990) Selective and nonselective stimulation of central cholinergic and dopaminergic development in vitro by nerve growth factor, basic fibroblast growth factor, epidermal growth factor, insulin and the insulin-like growth factors I and II. J Neurosci 10:558-570.

Lapchak PA, Hefti F (1991) Emerging pharmacology of nerve growth factor. Prog Neuropsychopharmacol Biol Psychiatry 15:851-860.

Matsuda S, Saito H, Nishiyama N (1990) Effect of basic fibroblast growth factor on neurons cultured from various regions of the rat brain. Brain Res 520:310-316.

Mattson MP, Dou P, Kater SB (1988) Outgrowth-regulating actions of glutamate in isolated hippocampal pyramidal neurons. J Neurosci 8:2087-2100.

McCarthy KD, de Vellis J (1980) Preparation of separate astroglial and oligodendroglial cell cultures from rat cerebral tissue. J Cell Biol 85:890-902.

Morrison RS, de Vellis J (1981) Growth of purified astrocytes in a chemically defined medium. Proc Natl Acad Sci USA 78:7205-7209.

Morrison RS, Sharma A, de Vellis J, Bradshaw RA (1986) Basic fibroblast growth factor supports the survival of cerebral cortical neurons in primary culture. Proc Natl Acad Sci USA 83:7537-7541.

Moscatelli D (1987) High and low affinity binding sites for basic fibroblast growth factor on cultured cells: absence of a role for low affinity binding in the stimulation of plasminogen activator production by bovine capillary endothelial cells. J Cell Physiol 131:123130.

Moscatelli D (1988) Metabolism of receptor-bound and matrix-bound basic fibroblast growth factor by bovine endothelial cells. J Cell Biol 107:753-759.

Moscatelli D, Joseph-Silverstein J, Manejias R, Rifkin DB (1987) $M_{r}$ 25,000 heparin-binding protein from guinea-pig brain is a high molecular weight form of basic fibroblast growth factor. Proc Natl Acad Sci USA 84:5779-5782.

Munson PJ, Rodbard D (1980) LIGAND: a versatile computerized approach for characterization of ligand-binding systems. Anal Biochem 107:220-239.

Murphy M, Drago J, Bartlett PF (1990) Fibroblast growth factor stimulates the proliferation and differentiation of neural precursor cells in vitro. J Neurosci Res 25:463-475.

Neufeld G, Ferrara N, Schweigerer L, Mitchell R, Gospodarowicz D (1987) Bovine granulosa cells produce basic fibroblast growth factor. Endocrinology 121:597-603.

Okumura N, Takimoto K, Okada M, Nakagawa H (1988) C6 glioma cells produce basic fibroblast growth factor that can stimulate their own proliferation. J Biochem 106:904-909.

Ono T, Saito H, Kishimoto T, Okumoto T, Miyamoto K (1991) Stimulation of biosynthesis of nerve growth factor by acidic fibroblast growth factor in cultured mouse astrocytes. Neurosci Lett 126:18-20.

Otto D, Unsicker K (1990) Basic FGF reverses chemical and morphological deficits in the nigrostriatal system of MPTP-treated mice. J Neurosci 10:1912-1921.

Otto D, Frotscher M, Unsicker K (1989) Basic fibroblast growth factor and nerve growth factor administered in gel foam rescue medial septal neurons after fimbria fornix transection. J Neurosci Res 22:83-91.

Pettmann B, Weibel M, Sensenbrenner M, Labourdette G (1985) Purification of two astroglial growth factors from bovine brain. FEBS Lett 189:102-108.

Pettmann B, Labourdette G, Weibel M, Sensenbrenner M (1986) The brain fibroblast growth factor (FGF) is localized in neurons. Neurosci Lett 68:175-180.

Prats H, Kaghad M, Prats AC, Klagsbrun M, Lelias JM, Liauzun P, Chalon P, Tauber JP, Amalric F, Smith JA, Caput D (1989) High molecular mass forms of basic fibroblast growth factor are initiated by alternative CUG codons. Proc Natl Acad Sci USA 86:1836-1840.

Pruss RM, Bartlett PF, Gavrilovic I, Lisak RP, Rattray S (1982) Mitogens for glial cells: a comparison of the response of cultured astrocytes, oligodendrocytes and Schwann cells. Dev Brain Res 2:19-35.

Quon D, Catalano R, Cordell B (1990) Fibroblast growth factor induces $\beta$-amyloid precursor mRNA in glial but not neuronal cultured cells. Biochem Biophys Res Commun 167:96-102.

Rifkin DB (1991) Biochemistry and cell biology of bFGF. Paper presented at the New York Academy of Science symposium on FGFs, La Jolla, California.

Saksela O, Rifkin DB (1990) Release of basic fibroblast growth factorheparan sulfate complexes from endothelial cells by plasminogen activator-mediated proteolytic activity. J Cell Biol 110:767-775.

Saneto RP, de Vellis J (1985) Characterization of cultured rat oligodendrocytes proliferating in a serum-free, chemically defined medium. Proc Natl Acad Sci USA 82:3509-3513.

Schweigerer L, Neufeld G, Friedman J, Abraham JA, Fiddes JC, Gospodarowicz D (1987) Capillary endothelial cells express basic fibroblast growth factor, a mitogen that promotes their own growth. Nature 325:257-259.

Stopa EG, Gonzalez AM, Chorsky R, Corona RJ, Alvarez J, Bird ED. Baird A (1990) Basic fibroblast growth factor in Alzheimer's disease. Biochem Biophys Res Commun 171:690-696.

Thomas KA (1987) Fibroblast growth factors. FASEB J 1:434-440.

Tsuboi R, Sato Y, Rifkin DB (1990) Correlation of cell migration, cell invasion, receptor number, proteinase production, and basic fibroblast growth factor levels in endothelial cells. J Cell Biol 110:511517.

Ueno N, Baird A, Esch F, Ling N, Guillemin R (1986) Isolation of an amino terminal extended form of basic fibroblast growth factor. Biochem Biophys Res Commun 138:580-588.

Unsicker K, Reichert-Preibsch H, Schmidt R, Pettmann B, Labourdette $G$, Scnsenbrenner M (1987) Astroglial and fibroblast growth factors have neurotrophic functions for cultured peripheral and central nervous system functions. Proc Natl Acad Sci USA 84:5459-5463.

Vlodavsky I, Folkman J, Sullivan R, Fridman R, Ishai-Michaeli R, Sasse J, Klagsbrun M (1987) Endothelial cell-derived basic fibroblast growth factor: synthesis and deposition into subendothelial extracellular matrix. Proc Natl Acad Sci USA 84:2292-2296. 
Walicke PA (1988a) Basic and acidic fibroblast growth factors have trophic effects on neurons from multiple CNS regions. J Neurosci 8: 2618-2627.

Walicke PA (1988b) Interactions between fibroblast growth factor (FGF) and glycosaminoglycans in promoting neurite outgrowth. Exp Neurol 102:144-148.

Walicke PA (1989) Novel neurotrophic factors, receptors, and oncogenes. Annu Rev Neurosci 12:103-126.

Walicke PA, Baird A (1988) Neurotrophic effects of basic and acidic fibroblast growth factors are not mediated through glial cells. Dev Brain Res 40:71-79.

Walicke PA, Cowan WM, Ueno N, Baird A, Guillemin R (1986) Fibroblast growth factor promotes survival of dissociated hippocampal neurons and enhances neurite extension. Proc Natl Acad Sci USA 83:3012-3016.
Walicke PA, Feige JJ, Baird A (1989) Characterization of the neuronal receptor for basic fibroblast growth factor and comparison to receptors on mesenchymal cells. J Biol Chem 264:4120-4126.

Wanaka A, Johnson EM Jr, Milbrandt J (1990) Localization of FGF receptor mRNA in the adult rat central nervous system by in situ hybridization. Neuron 5:267-281.

Whitson JS, Glabe CG, Shintani E, Abcar A, Cotman CW (1990) $\beta$-Amyloid protein promotes neuritic branching in hippocampal cultures. Neurosci Lett 110:319-324.

Yoshida K, Gage FH (1991) Fibroblast growth factors stimulate nerve growth factor synthesis and secretion by astrocytes. Brain Res 538: 118-126. 